\title{
Some observations about cochlear implants: challenges and future directions
}

\author{
Kathleen F. Faulkner* and David B. Pisoni \\ *Correspondence: katieff@indiana.edu \\ Department of Psychological and Brain Sciences, Indiana University 1101 E. $10^{\text {th }}$ Street, Bloomington, USA.
}

\begin{abstract}
At the present time, cochlear implantation is the only available medical intervention for patients with profound hearing loss and is considered the "standard of care" for both prelingually deaf infants and post-lingually deaf adults. It has been suggested recently that cochlear implants are one of the greatest accomplishments of auditory neuroscience. Despite the enormous success of cochlear implantation for the treatment of profound deafness, especially in young prelingually deaf children, several pressing unresolved clinical issues have emerged that are at the forefront of current research efforts in the field. In this commentary we briefly review how a cochlear implant works and then discuss five of the most critical clinical and basic research issues: (1) individual differences in outcome and benefit, (2) speech perception in noise, (3) music perception, (4) neuroplasticity and perceptual learning, and (5) binaural hearing.
\end{abstract}

Keywords: Cochlear implants, auditory prostheses, deafness, signal processing

\section{Introduction and background}

Cochlear implantation $(\mathrm{Cl})$ is currently the only FDA-approved medical treatment available to partially restore hearing in patients with severe-to-profound sensorineural hearing loss. Cls are often cited as one of the greatest accomplishments of auditory neuroscience, an example of truly translational science linking basic research on hearing to clinical application [1,2]. Cls were first approved by the FDA for adults in 1985, and then for children in 1990. As of 2011, the NIH reported that 219,000 patients had received Cls worldwide, with 42,600 adults and 28,400 children implanted in the United States [3]. This number is increasing rapidly; by 2013 , the number of Cls is estimated at more than 320,000, with almost 40,000 recipients implanted bilaterally [4].

$\mathrm{Cl}$ candidates are patients who receive little benefit from hearing aids. Rather than just amplifying an acoustic signal like conventional hearing aids do, Cls convert sound patterns into electrical signals which are then delivered directly to the spiral ganglion cells and the auditory nerve (See Figure 1. for an illustration of a cochlear implant). The signal processing carried out by a $\mathrm{Cl}$ is complex: the range of incoming amplitude levels is first compressed resulting in a reduced dynamic range, and the bandwidths of component frequencies are greatly reduced. Depending on placement within the cochlea, a tonotopic mismatch in frequency-to-place alignment may occur [5].

In addition, numerous device- and patient-related factors often limit how frequency and intensity information in complex sounds like speech and music are encoded and used by patients. The age and criterion for $\mathrm{Cl}$ candidacy have also changed dramatically over time. $\mathrm{Cl}$ candidacy is currently determined by the degree of hearing loss (severe-to-profound bilateral sensorineural hearing loss $\geq 70 \mathrm{~dB}$ ) and limited benefit from binaural hearing aids following a 3-6 month trial with appropriately fitted current technology.

Benefits for children and adults with $\mathrm{Cls}$ are routinely assessed with tests of spoken word recognition and sentence perception in the quiet [6]. For prelingually deaf children, outcome measures also include assessment of receptive and expressive language development and speech intelligibility [e.g., 6,7]. Performance with $\mathrm{Cls}$ has consistently improved over time due to developments in signal-processing technology and changes in candidacy criteria (see Figure 2) [8]. However, large individual differences in performance are universally reported, from "excellent" high-functioning $\mathrm{Cl}$ users, often called "Stars," who do exceptionally well on open-set speech perception tasks to low-functioning $\mathrm{Cl}$ users who often receive little or no benefit beyond basic awareness of sound and assistance with lipreading $[9,10]$. Individual differences in outcome and benefit result from a combination of sources including the degraded signal provided at the peripheral level, how robustly the information has been encoded through the central auditory pathways, and how well an individual user can "match" the new transformed acoustic signal to neural and cognitive representations in their long-term memory. All behavioral measures used to assess outcome and benefit are the final product of a long series of complex information processing operations [11].

Counseling hearing-impaired listeners is a very important component of the candidacy evaluation process to ensure that patients have realistic expectations about the range of possible outcomes following implantation. Audiologists inform 


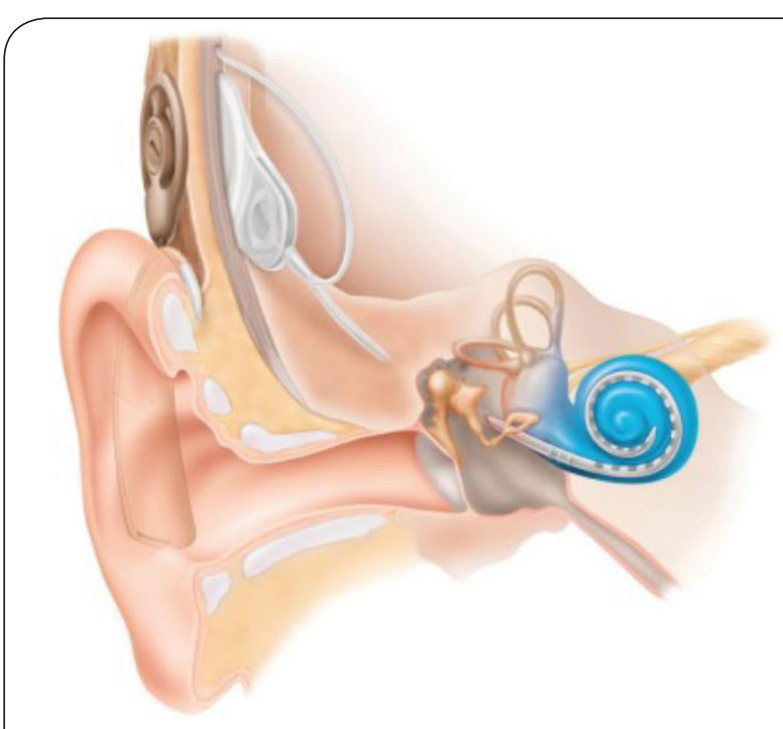

Figure 1. Illustration of a cochlear implant. A cochlear implant consists of internal and external components. The external portion (brown) contains a microphone, signal processor, and RF transmitter. The implanted portion contains an RF antenna receiver, a signal decoder, and a stimulus generator. The cochlear implant electrode array, containing 12-22 electrode contacts, is inserted into the scala tymapni of the cochlea (blue). Acoustic signals received at the microphone are processed, coded, and transmitted to the internal electronics. The received signal is then decoded and sent to the appropriate tonotopically arranged electrodes in the cochlea (Courtesy of Robert Shannon [8]).

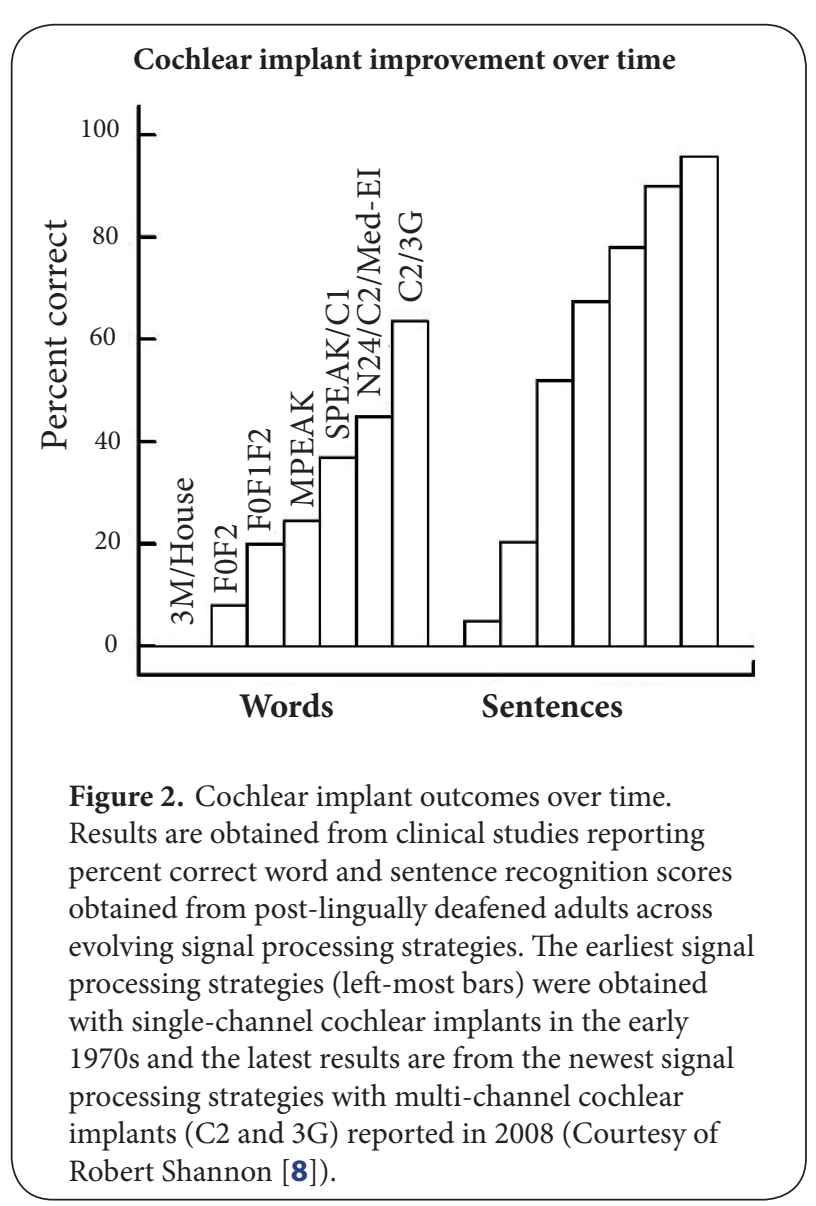

information like this in the media, it is not surprising that many profoundly deaf patients seek out $\mathrm{Cls}$ with unrealistic expectations about potential outcomes and benefits. Cls do not "restore" normal hearing and, like most medical treatments, they do not provide benefit for all patients who receive this medical intervention.

\section{Current research directions}

Despite the enormous success of cochlear implantation for the treatment of profound deafness, especially in young prelingually deaf children, several pressing unresolved clinical issues have emerged that are at the forefront of current research efforts in the field [14]. Below we summarize five of the most critical problems: (1) individual differences in outcome and benefit, (2) speech perception in noise, (3) music perception, (4) neuroplasticity and perceptual learning, and (5) binaural hearing.

\section{Individual differences in outcome and benefit}

Many deaf adults and children do very well with their $\mathrm{Cls}$, often approaching the performance of age-matched normal hearing peers under quiet testing conditions, while other patients with Cls obtain little benefit, scoring less than 50\% signal to the brain in terms of the range of frequencies and intensities when compared with normal hearing [8]. With 
correct on word recognition tests [e.g., 7,9,12,15]. Benefit with $\mathrm{a} \mathrm{Cl}$ is routinely assessed with speech/language measures and quality of life assessments. All patients with Cls experience a great deal of difficulty understanding speech in background noise or under high cognitive loads. When compared to other medical interventions, there is universal agreement among speech and hearing scientists that variability in speech and language outcomes is the most important and most challenging unresolved problem in the field today [e.g., 15-18].

The restoration of hearing function in most post-lingually deaf adults and children, as well as prelingually deaf infants and young children, is remarkable and exceeds the performance of other neural prostheses that have been developed for other sensory modalities $[1,8,19]$. There is no question that $\mathrm{Cls}$ work and work well in many patients who are candidates for this kind of medical intervention. However, Cls do not work equally well in all patients and this is a significant clinical and pressing problem.

For example, early research with Cls focused on the "Stars" the extraordinary good Cl users - as a "proof of principle" to demonstrate "efficacy" that Cls work. More recently, research efforts have shifted to the investigation of the "effectiveness" of Cls, focusing on the "poor" or low-functioning $\mathrm{Cl}$ users who fail to achieve the expected benefits from their $\mathrm{Cls}$ [e.g., $15,20-22]$. The enormous variability in speech and language outcomes is not surprising given the heterogeneity of hearing loss. Each patient is unique and presents with a different developmental history and genetic profile that may contribute to their prognosis. It is unlikely that any one factor can successfully predict speech and language outcomes in all $\mathrm{Cl}$ patients, because the observed variance reflects complex multi-parametric interactions distributed across many domains. Strong predictors (or "risk factors") are historically tied to: (1) the patient (e.g., demographics: age, age at implantation, degree of deafness, duration of deafness, hearing aid use, residual hearing), (2) the environment (e.g., access to early intervention, SES, communication mode), and (3) the device (e.g., generation of implant, surgical technique, active channels, dynamic range). While these strong predictors provide an initial foundation for predicting potential outcomes for the majority of $\mathrm{Cl}$ users, a substantial amount of variance still remains unexplained [e.g., 5,23-25]. The unexplained variability exists in domains that have not been previously explored by conventional clinical assessments. All medical interventions have variability, and have well-known risk factors associated with them. In the case of $\mathrm{Cls}$, predicting outcome and benefit remains a significant challenge in the field of Neuro-otology.

\section{Measuring outcomes in adults and children}

Outcomes are routinely measured with a battery of behavioral tests. For adults, basic hearing thresholds for tones and word and sentence recognition scores are the primary assessment measures. Many $\mathrm{Cl}$ patients achieve very high levels of speech perception in the quiet, often reaching ceiling levels of performance with conventional testing materials [16]. These improvements are a result of a combination of factors, including improved cochlear implant technology, better signal processing algorithms, and changes in candidacy criteria (i.e., implanting patients with less severe hearing losses) (see Figure 2). Early assessments of $\mathrm{Cl}$ performance included closed-set testing materials whereby the listener is provided with a short list of possible response alternatives, as well as open-set word and sentence recognition tests. While many word and sentence test batteries are available for use with $\mathrm{Cl}$ patients all over the world [6], a standard test protocol called the Minimum Speech Test Battery (MSTB) was adopted in 1996 by a committee of auditory scientists, clinicians, and cochlear implant manufacturers to provide a comprehensive set of standardized speech measures for use in comparing results across implant centers and clinics $[26,27]$. This battery has recently been updated to reflect changes in the performance of current $\mathrm{Cl}$ users, including more challenging sentence recognition materials presented in quiet and in multi-talker babble noise $[\mathbf{2 8}, \mathbf{2 9}]$. These assessment instruments provide a greater range of variability allowing for the measurement of changes in performance over time, especially for higher performing patients [16]. Measures of self-assessed quality of life also provide another way to assess benefit following cochlear implantation [30-35].

For children, test materials used in evaluating outcome and benefit are based on the age and ability of the child, and assess the development of expressive and receptive language and perceptual abilities, through behavioral observation, testing, and caregiver reports [36]. The development of speech perception is typically evaluated in a hierarchical fashion [37], from basic detection of sounds to spoken word recognition, where children "graduate" to more difficult testing materials as they move along the developmental trajectory [38-40]. The skill level of the child determines the chosen test materials, from assessment for candidacy through tracking performance over time following implantation and monitoring the success of speech and language intervention strategies. For very young children, this involves monitoring several stages of sound/speech perception (e.g., Infant-Toddler Meaningful Auditory Integration Scale: IT-MAIS [41]).

\section{Pre-versus post-lingually deafened adults}

For adult patients seeking a $\mathrm{Cl}$, candidates whose deafness occurred after the acquisition of speech and language typically outperform adult patients with congenital or earlyacquired deafness. The benefits from $\mathrm{Cls}$ in prelingually deaf adults who have been deaf for many years is quite poor due to the long period of auditory deprivation, delay in spoken language development, and substantial neural reorganization of underlying cortical brain circuits [42]. Most Neuro-otologists will not implant deaf adult patients who have long-term prelingual profound deafness because restoration of hearing and speech and language outcomes has been shown to be 
Faulkner et al. Neuroscience Discovery 2013,

poor and $\mathrm{Cls}$ provide little benefit even with long-term use [43-46]. Moreover, even in post-lingually deafened patients who are deemed to be acceptable candidates for $\mathrm{Cls}$, the individual differences in speech and language outcomes are enormous and remain largely unexplained by conventional demographic, medical, and device factors.

\section{Prelingually deaf children}

Prelingually deaf infants and children are a fundamentally different clinical population because their hearing loss occurs during the process of speech and language development. A sensory deficit occurring during this critical period of neural and cognitive development has profound effects on later speech, language, and cognition $[\mathbf{1 4 , 4 7 , 4 8}]$. It is generally believed that children implanted under two years of age will have the best speech and language outcomes [e.g., 7,23,49-54]. Many speech and hearing scientists believe that early implantation maximizes the critical period and takes advantage of the neural plasticity in younger populations [2]. Some researchers have even suggested that earlyimplanted children will "catch-up" to their normal-hearing peers [55]. Unfortunately, no single factor has been found that is necessary and sufficient to reliably predict speech and language outcomes in all patients.

\section{Speech in noise}

Understanding speech in noise is the most frequent and challenging problem facing patients with $\mathrm{Cls}$, and is a central topic of current research. It takes a whole brain to understand speech, which is especially true when listeners attempt to understand speech in a background of other competing voices [56]. Outcomes and benefits following cochlear implantation are typically measured in the clinic or laboratory using word and sentence materials presented in the quiet. The results of these tests provide important baseline information about how a patient performs under optimal conditions, but they do not reflect common everyday listening environments. To perform well in real-world noisy conditions, listeners must quickly adapt, switch their attention, and adjust to multiple sources of variability in both the signal and listening environments. Sentence recognition tests in noise are useful for assessing speech understanding abilities because they require a combination of basic sensory and perceptual abilities as well as elementary neurocognitive resources and processing operations [e.g., 11]. All Cl patients routinely experience difficulty in listening to speech in the presence of background noise or over the telephone, and they have an even more difficult time listening to speech in fluctuating noise, such as multi-talker babble in meetings and restaurants where many people are talking at the same time $[18,57,58]$.

At the peripheral auditory level, hearing scientists believe that the difficulties $\mathrm{Cl}$ patients experience arise primarily from poor spectral resolution due to channel interaction across stimulated electrodes [e.g., 59,60]. Much of the current research efforts to improve speech in noise have targeted the "front-end" or early sensory processing and neural encoding of speech sounds using novel coding strategies and noise reduction algorithms [61-64]. Another avenue has been to identify $\mathrm{Cl}$ channels with the best electrode-neural-interface and either simply deactivate the problematic channels in the patient's speech processor map, or reduce the degree of channel interactions among electrodes by using signal processing strategies employing focused current [17,65-67].

Some researchers have now begun to assess the role of attention and cognition in individuals using a $\mathrm{Cl}$. For example, performance on a speech in noise task can be measured by determining the signal to noise ratio (SNR) needed for a patient to achieve $50 \%$ correct on a word identification in noise task. However, this score may not accurately reflect the amount of cognitive effort that a patient has to expend to reach this criterion. The concept of cognitive load, that some tasks require more mental effort and processing resources, is not a new concept $[68,69]$ and reflects a core principle that the cognitive system has finite processing resources. When one task becomes more difficult, in this case trying to understand speech that is both degraded and mixed with competing noise, additional effort is necessary to maintain performance. Neurocognitive measures have been employed recently to assess the information processing workload demands required for listening to speech in background noise for $\mathrm{Cl}$ listeners $[70,71]$ and normal hearing participants under $\mathrm{Cl}$ simulation [72]. Some of these behavioral measures rely on self-report [73], speed of processing [74,75], physiological responses such as pupillometry [77], or "dual-task" methodologies to assess listening effort and mental workload [78-79].

\section{Music perception}

Many adults with $\mathrm{Cls}$ are very disappointed that they can no longer hear and appreciate music after receiving their $\mathrm{Cl}$. Impairments in music perception are often reported as significant negative factors in self-reports of quality of life [31]. Many postlingual $\mathrm{Cl}$ patients show poor music perception on behavioral tests and uniformly report decreased enjoyment in listening to music following $\mathrm{Cl}$ [80-83]. Recently, Limb and Roy [84] have identified several technological, sensory, and acoustical constraints that limit $\mathrm{Cl}$ users from perceiving music through a $\mathrm{Cl}$. These include poor representation of the spectral-temporal fine structure of music, as well as the long-term neurobiological effects of auditory deprivation. Recognizing speech in noise and listening to music rely heavily on robust encoding of spectral information in complex time-varying signals. Normal hearing listeners tested under $\mathrm{Cl}$ acoustic simulations have shown that only 4-8 channels of information are required for speech recognition in the quiet $[85,86]$; Additional channels are required for speech recognition in background noise, and often more than 48 channels are needed for music recognition [85-87].

Current research efforts exploring novel signal processing 
schemes to improve the encoding of the temporal fine structure of complex time-varying acoustic signals may provide additional information and lead to significant improvements in music perception as well as speech perception in noise [e.g., 88]. Further, targeted individualized auditory training using complex spectral and temporal patterns may lead to additional improvements in music perception [89-93]. Despite the availability of music perception tasks for clinical use, music perception is not routinely assessed clinically by audiologists who are primarily interested in speech recognition outcomes $[89,90,94,95]$.

\section{Neuroplasticity and perceptual learning}

There are profound peripheral and central effects in the auditory pathway as a result of sensory deprivation and stimulation with a $\mathrm{Cl}[$ see $1, \mathbf{1 9}, \mathbf{4 8 , 9 6 ]}$. The fact that many prelingually deaf children and post-lingual deaf adults obtain significant benefit with a $\mathrm{Cl}$ serves as an existence proof of neural plasticity following implantation. However, the structural integrity of the central auditory system may significantly limit the capacity for change in some individuals, either due to the duration of deafness resulting in profound neural degeneration (local or central) or significant cortical neural reorganization and cross-modal interference $[\mathbf{1 , 2 , 4 8}$. Children implanted younger than two years of age may have an advantage for neural plasticity, as demonstrated through cortically evoked potentials, while older children may have diminished neural plasticity $[97,98]$.

All medical prostheses require extensive rehabilitation. In contrast, an adult patient who receives his or her $\mathrm{Cl}$ is routinely sent home to experience their auditory world without any structured rehabilitation program in place. The lack of evidence-based auditory training methodologies combined with the absence of insurance reimbursement for clinical audiologists to manage intervention protocols may be to blame. Patients may continue to improve their performance for up to one year or more following $\mathrm{Cl}$ [12]; however it may be possible to enhance the process of adapting to the implant with individualized focused training and other perceptual learning techniques [e.g., 99-101]. Several recent studies have explored auditory training techniques with cochlear implant patients; unfortunately, success has been mixed $[102,103]$. One problem with current auditory training studies has been their focus on developing training protocols that are related to the patient's clinical difficulties rather than on understanding the causal factors underlying the deficits that lead to the observed performance decrements. All auditory training studies have consistently reported difficulties in demonstrating robust transfer of training. If a $\mathrm{Cl}$ patient improves on a training protocol in the clinic, lab, or even at home, there is little evidence that this training will also improve the patient's ability to perceive speech or communicate in everyday real-world conditions in daily life. Current research efforts are now focused on identifying the core fundamental components of auditory training and perceptual learning that will produce robust improvements and transfer effects [104].

\section{Binaural hearing}

Hearing with two ears provides several significant benefits, such as locating a sound source (localization), improved speechin-noise performance, and dereverberation of competing acoustic signals in the real-world [105]. These binaural hearing advantages arise from two primary cues-sounds arrive sooner (interaural timing difference, ITD) and at a greater intensity (interaural level difference, ILD) to the ear that is closer to the sound source. Unilateral $\mathrm{Cl}$ users do not have access to either of these two robust binaural hearing cues. Restoring binaural hearing with two $\mathrm{Cls}$ could lead to significant improvements such as speech perception in noise, sound source localization, and attention/inhibition of reverberation in the environment [106-109]. However, current bilateral $\mathrm{Cl}$ users may not be able to make use of these interaural timing and intensity cues because current clinical strategies and mapping techniques do not coordinate the inputs from the two separate Cls like the binaural auditory system does in normal hearing listeners. Further, there is significant mismatched alignment of the electrodes (insertion depth), and the corresponding channels are often not balanced for loudness [110,111]. Additionally, deprivation-related disturbances and neural reorganization in binaural circuitry and auditory cortex may limit the capacity of the damaged auditory system to recover and utilize these binaural time and intensity cues [112]. Despite these challenges, bilateral cochlear implantation is becoming more common, with many prelingually deaf infants and young children now undergoing simultaneous bilateral cochlear implantation $[113,114]$. However, many bilateral $\mathrm{Cl}$ patients often receive their second $\mathrm{Cl}$ sequentially often after long time intervals between surgeries. This is not an optimal strategy because there is substantial evidence documenting a narrow sensitive period for the development of binaural hearing [115-121], although the binaural system shows some degree of plasticity into adulthood and sensitivity to these cues may improve with experience [122-124]. A common misconception in the media is that "if one $\mathrm{Cl}$ is good, then two must be better." However, this is not always the case and, in some cases, a second $\mathrm{Cl}$ offers no demonstrable benefit over one [e.g., 120,125,126]. Binaural hearing in $\mathrm{Cl}$ users can be achieved through the use of two Cls (bilateral) or through a combination of Cls and hearing aids across the ears (bimodal or electroacoustic). Bimodal listeners are those patients who have some residual low-frequency hearing and wear a hearing aid on their contralateral ear. The choice of a second $\mathrm{Cl}$ is controversial in these patients because they may be better able to access some useful binaural hearing cues via their remaining lowfrequency acoustic hearing [127].

\section{Conclusions}

The field of Cls has many pressing unresolved clinically- 
Faulkner et al. Neuroscience Discovery 2013,

relevant questions that would benefit substantially from a broader neurobiological perspective, particularly as the number of $\mathrm{Cl}$ patients increases and the criteria for candidacy continues to evolve. Individual differences in outcome and benefit remain a significant focus of current research to understand additional sources of variability beyond the strong demographic predictors. Incorporating more ecologically valid measures of speech in noise, music perception, listening effort, and quality of life may provide valuable assessments of benefit beyond speech perception in the quiet in evaluating gains following auditory training, or from the use of novel $\mathrm{Cl}$ processing strategies. Finally, while bilateral Cls appear to provide additional benefit for many patients, particularly those who receive their implants simultaneously at a young age, more research is necessary to determine how best to provide listeners with access to binaural hearing cues.

\section{Future directions}

The ear does not work in isolation from the rest of the brain; it is an inseparable component of a complex highly organized information processing system [128]. The contribution of neurocognition to hearing is a new and growing direction of research for people with hearing loss [129]. This approach to hearing and speech perception adopts a "systems approach" linking early auditory processing to higher-level neurocognitive functions such as attention, cognitive control, executive function, inhibition, learning, and memory. Research on $\mathrm{Cls}$ is now becoming situated within a broader theoretical and conceptual framework of neurocognitive and human information processing reflecting a foundational assumption that the brain and nervous system work together in an integrative and connected fashion [14]. By viewing the brain as a processor of information that maps sensory inputs to perception, cognition, and action, new and better ways to assess outcomes and benefits and develop novel intervention strategies become available.

When viewed in this broader theoretical context, we suggest that combining efforts among numerous diverse research groups, individualizing mapping based on patientspecific factors, using highly advanced signal processing, and promoting robust perceptual learning through novel auditory training techniques will prove to be the most successful approach to helping low-functioning $\mathrm{Cl}$ patients reach optimal levels of speech and language performance. More importantly, employing a system-level neurobiological approach to these complex problems will help to identify the core foundational underlying sensory, neural, and cognitive processing mechanisms and factors responsible for the enormous individual differences in outcome and benefit following $\mathrm{Cl}$. We are confident that the clinical benefits of Cls will be improved significantly once we know and fully understand the foundational mechanisms of action responsible for the variability in speech and language outcomes, especially in the patients who are performing poorly with their Cls.
Competing interest

The authors declare that they have no competing interests.

\section{Authors' contributions}

\begin{tabular}{|l|c|c|}
\hline Authors' contributions & KFF & DBP \\
\hline Research concept and design & $\checkmark$ & $\checkmark$ \\
\hline Collection and/or assembly of data & -- & -- \\
\hline Data analysis and interpretation & -- & -- \\
\hline Writing the article & $\checkmark$ & $\checkmark$ \\
\hline Critical revision of the article & $\checkmark$ & $\checkmark$ \\
\hline Final approval of article & $\checkmark$ & $\checkmark$ \\
\hline Statistical analysis & -- & -- \\
\hline
\end{tabular}

\section{Acknowledgement}

The research of the authors has been supported, in part, by NIDCD grants R01 DC-00111, R01 DC-009581, and T32 DC-00012. We thank the editor and two anonymous reviewers for their helpful comments.

\section{Publication history}

EIC: Tadanori Tomita, Northwestern University Feinberg School of Medicine, USA.

Received: 28-Aug-2013 Revised: 02-Oct-2013

Accepted: 12-Oct-2013 Published: 26-Oct-2013

\section{References}

1. Wilson BS and Dorman MF. Cochlear implants: current designs and future possibilities. J Rehabil Res Dev. 2008; 45:695-730. | Article | PubMed

2. Moore DR and Shannon RV. Beyond cochlear implants: awakening the deafened brain. Nat Neurosci. 2009; 12:686-91. | Article I PubMed

3. Mudry A and Mills M. The early history of the cochlear implant: a retrospective. JAMA Otolaryngol Head Neck Surg. 2013; 139:446-53. | Article | PubMed

4. Strauss E. Lasker Foundation. 2013. | Website

5. Svirsky MA, Silveira A, Neuburger $H$, Teoh SW and Suarez H. Long-term auditory adaptation to a modified peripheral frequency map. Acta Otolaryngol. 2004; 124:381-6. | PubMed

6. Kirk KI and Choi S. Clinical investigations of cochlear implant performance. In Niparko JK, Kirk KI, McConkey Robbins AM, Mellon NK, Tucci DL, Wilson BS (Eds) Cochlear Implants: Principles and Practices. 2nd ed. Philadelphia: Lippincott Williams \& Wilkins. 191-222. | Book

7. Niparko JK, Tobey EA, Thal DJ, Eisenberg LS, Wang NY, Quittner AL and Fink NE. Spoken language development in children following cochlear implantation. JAMA. 2010; 303:1498-506. | Article | PubMed Abstract | PubMed Full Text

8. Shannon RV. Restoration of Hearing by Electrical Stimulation of the Human Cochlea, Brainstem, and Midbrain. In: Hung GK (Ed.), Biomedical Engineering: Principles of the Bionic Man. 2010; 205-232. | Book

9. Skinner MW, Clark GM, Whitford LA, Seligman PM, Staller SJ, Shipp DB, Shallop JK, Everingham C, Menapace CM, Arndt PL and et al. Evaluation of a new spectral peak coding strategy for the Nucleus 22 Channel Cochlear Implant System. Am J Otol. 1994; 15 Suppl 2:15-27. I PubMed

10. Firszt JB, Holden LK, Skinner MW, Tobey EA, Peterson A, Gaggl W, Runge-Samuelson $C L$ and Wackym PA. Recognition of speech presented at soft to loud levels by adult cochlear implant recipients of three cochlear implant systems. Ear Hear. 2004; 25:375-87. | Article | PubMed 
11. Pisoni DB. Cognitive factors and cochlear implants: some thoughts on perception, learning, and memory in speech perception. Ear Hear. 2000; 21:70-8. | Article | PubMed Abstract | PubMed Full Text

12. Krueger B, Joseph G, Rost U, Strauss-Schier A, Lenarz T and Buechner A. Performance groups in adult cochlear implant users: speech perception results from 1984 until today. Otol Neurotol. 2008; 29:50912. | Article | PubMed

13. Clark A. Natural-Born Cyborgs. 2004. | Website

14. O'Donoghue GM and Pisoni DB. Auditory and Lingustic Outcomes in Pediatric Cochlear Implantation. In: Waltzman SB, Roland JT (Eds.) Cochlear Implants. 3rd ed. Thieme Medical Publishers, 2013. | Book

15. Wilson BS, Dorman MF, Woldorff MG and Tucci DL. Cochlear implants matching the prosthesis to the brain and facilitating desired plastic changes in brain function. Prog Brain Res. 2011; 194:117-29. | Article | PubMed Abstract | PubMed Full Text

16. Gifford RH, Shallop JK and Peterson AM. Speech recognition materials and ceiling effects: considerations for cochlear implant programs. Audiol Neurootol. 2008; 13:193-205. | Article | PubMed

17. Gifford RH and Revit LJ. Speech perception for adult cochlear implant recipients in a realistic background noise: effectiveness of preprocessing strategies and external options for improving speech recognition in noise. J Am Acad Audiol. 2010; 21:441-51; quiz 487-8. Article I PubMed

18. Caldwell A and Nittrouer S. Speech perception in noise by children with cochlear implants. J Speech Lang Hear Res. 2013; 56:13-30. | Article | PubMed

19. Wilson BS and Dorman MF. Cochlear implants: a remarkable past and a brilliant future. Hear Res. 2008; 242:3-21. | Article I PubMed Abstract | PubMed Full Text

20. Bierer JA and Faulkner KF. Identifying cochlear implant channels with poor electrode-neuron interface: partial tripolar, single-channel thresholds and psychophysical tuning curves. Ear Hear. 2010; 31:24758. | Article | PubMed Abstract | PubMed Full Text

21. Bierer JA, Faulkner KF and Tremblay KL. Identifying cochlear implant channels with poor electrode-neuron interfaces: electrically evoked auditory brain stem responses measured with the partial tripolar configuration. Ear Hear. 2011; 32:436-44. I Article I PubMed Abstract | PubMed Full Text

22. Noble JH, Labadie RF, Gifford RH and Dawant BM. Image-guidance enables new methods for customizing cochlear implant stimulation strategies. IEEE Trans Neural Syst Rehabil Eng. 2013; 21:820-9.| Article | PubMed

23. Geers AE, Nicholas JG and Moog JS. Estimating the Influence of Cochlear Implantation on Language Development in Children. Audiol Med. 2007; 5:262-273. | Article | PubMed Abstract | PubMed Full Text

24. Archbold S, O'Donoghue GM. Cochlear implantation in children: current status.Paediatrics and Child Health 2009, 19(10):457-463. | Article

25. Pisoni DB, Cleary M, Geers AE and Tobey EA. Individual Differences in Effectiveness of Cochlear Implants in Children Who Are Prelingually Deaf: New Process Measures of Performance. Volta Rev. 1999; 101:111-164. | PubMed Abstract | PubMed Full Text

26. Nilsson JM, McCaw VM and Soli SD. Speech test battery for adult cochlear implant users. House Ear Institute; 1996.

27. Luxford WM. Minimum speech test battery for postlingually deafened adult cochlear implant patients. Otolaryngol Head Neck Surg. 2001; 124:125-6. | Article | PubMed

28. Spahr AJ, Dorman MF, Litvak LM, Van Wie S, Gifford RH, Loizou PC, Loiselle LM, Oakes T and Cook S. Development and validation of the AzBio sentence lists. Ear Hear. 2012; 33:112-7. | Article | PubMed

29. Spahr AJ and Dorman MF. Performance of subjects fit with the
Advanced Bionics $\mathrm{CII}$ and Nucleus 3G cochlear implant devices. Arch Otolaryngol Head Neck Surg. 2004; 130:624-8. I Article I PubMed

30. Gaylor JM, Raman G, Chung M, Lee J, Rao M, Lau J and Poe DS. Cochlear implantation in adults: a systematic review and metaanalysis. JAMA Otolaryngol Head Neck Surg. 2013; 139:265-72. | Article I PubMed

31. Cox RM and Alexander GC. The abbreviated profile of hearing aid benefit. Ear Hear. 1995; 16:176-86. | Article | PubMed

32. Cox R, Hyde M, Gatehouse S, Noble W, Dillon H, Bentler R, Stephens D, Arlinger S, Beck L, Wilkerson D, Kramer S, Kricos P, Gagne JP, Bess F and Hallberg L. Optimal outcome measures, research priorities, and international cooperation. Ear Hear. 2000; 21:106S-115S. | Article | PubMed

33. Gatehouse S and Noble W. The Speech, Spatial and Qualities of Hearing Scale (SSQ). Int J Audiol. 2004; 43:85-99. | Article I PubMed

34. Noble W and Gatehouse S. Effects of bilateral versus unilateral hearing aid fitting on abilities measured by the Speech, Spatial, and Qualities

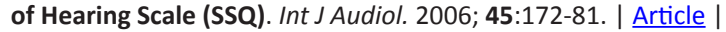
PubMed

35. Mertens G, Punte AK and Van de Heyning P. Self-Assessment of Hearing Disabilities in Cochlear Implant Users Using the SSQ and the Reduced SSQ5 Version. Otol Neurotol. 2013. | Article | PubMed

36. Lin FR, Wang NY, Fink NE, Quittner AL, Eisenberg LS, Tobey EA and Niparko JK. Assessing the use of speech and language measures in relation to parental perceptions of development after early cochlear implantation. Otol Neurotol. 2008; 29:208-13. | Article | PubMed Abstract | PubMed Full Text

37. Erber N. Auditory Training. Washington, DC: AG Bell; 1982.

38. Geers AE. Speech, language, and reading skills after early cochlear implantation. Arch Otolaryngol Head Neck Surg. 2004; 130:634-8. I Article I PubMed

39. Eisenberg LS, Johnson KC, Martinez AS, DesJardin JL, Stika CJ, Dzubak $D$, Mahalak ML and Rector EP. Comprehensive evaluation of a child with an auditory brainstem implant. Otol Neurotol. 2008; 29:251-7. | Article | PubMed

40. Wang NY, Eisenberg LS, Johnson KC, Fink NE, Tobey EA, Quittner AL and Niparko JK. Tracking development of speech recognition: longitudinal data from hierarchical assessments in the Childhood Development after Cochlear Implantation Study. Otol Neurotol. 2008; 29:240-5. | Article | PubMed Abstract | PubMed Full Text

41. Zimmerman-Phillips S, Robbins AM and Osberger MJ. Assessing cochlear implant benefit in very young children. Ann Otol Rhinol Laryngol Suppl. 2000; 185:42-3. | PubMed

42. Kral A and Eggermont JJ. What's to lose and what's to learn: development under auditory deprivation, cochlear implants and limits of cortical plasticity. Brain Res Rev. 2007; 56:259-69. | Article | PubMed

43. Teoh SW, Pisoni DB and Miyamoto RT. Cochlear implantation in adults with prelingual deafness. Part I. Clinical results. Laryngoscope. 2004; 114:1536-40. | Article | PubMed Abstract | PubMed Full Text

44. Teoh SW, Pisoni DB and Miyamoto RT. Cochlear implantation in adults with prelingual deafness. Part II. Underlying constraints that affect audiological outcomes. Laryngoscope. 2004; 114:1714-9. | Article | PubMed Abstract | PubMed Full Text

45. Waltzman SB, Roland JT, Jr. and Cohen NL. Delayed implantation in congenitally deaf children and adults. Otol Neurotol. 2002; 23:333-40. | Article | PubMed

46. Waltzman SB, Roland JT, Jr. and Cohen NL. Delayed implantation in congenitally deaf children and adults. Otol Neurotol. 2002; 23:333-40. | Article | PubMed

47. Luria AR. The working brain: An introduction to neuropsychology. 
Faulkner et al. Neuroscience Discovery 2013,

http://www.hoajonline.com/journals/pdf/2052-6946-1-9.pdf

doi: 10.7243/2052-6946-1-9

\section{6. | Book}

48. Kral A and Sharma A. Developmental neuroplasticity after cochlear implantation. Trends Neurosci. 2012; 35:111-22. | Article | PubMed Abstract | PubMed Full Text

49. Tajudeen BA, Waltzman SB, Jethanamest D and Svirsky MA. Speech perception in congenitally deaf children receiving cochlear implants in the first year of life. Otol Neurotol. 2010; 31:1254-60. | Article | PubMed Abstract | PubMed Full Text

50. Geers AE. Factors affecting the development of speech, language, and literacy in children with early cochlear implantation.Lang Sp Hear Serv in Schools 2002, 33:172-183. | Article

51. Geers A, Tobey E, Moog J and Brenner C. Long-term outcomes of cochlear implantation in the preschool years: from elementary grades to high school. Int J Audiol. 2008; 47 Suppl 2:S21-30. | Article | PubMed

52. Geers AE, Moog JS, Biedenstein J, Brenner $\mathrm{C}$ and Hayes H. Spoken language scores of children using cochlear implants compared to hearing age-mates at school entry. J Deaf Stud Deaf Educ. 2009; 14:371-385. | Article

53. Tobey EA, Thal D, Niparko JK, Eisenberg LS, Quittner AL and Wang NY. Influence of implantation age on school-age language performance in pediatric cochlear implant users. Int J Audiol. 2013; 52:219-29. | Article | PubMed

54. Nicholas JG and Geers AE. Will they catch up? The role of age at cochlear implantation in the spoken language development of children with severe to profound hearing loss. I Speech Lang Hear Res. 2007; 50:1048-62. | Article | PubMed Abstract | PubMed Full Text

55. Nicholas JG and Geers AE. Spoken language benefits of extending cochlear implant candidacy below 12 months of age. Otol Neurotol. 2013; 34:532-8. | Article | PubMed

56. Obleser J, Wise RJ, Alex Dresner M and Scott SK. Functional integration across brain regions improves speech perception under adverse listening conditions. J Neurosci. 2007; 27:2283-9. | Article | PubMed

57. Stickney GS, Loizou PC, Mishra LN, Assmann PF, Shannon RV and Opie JM. Effects of electrode design and configuration on channel interactions. Hear Res. 2006; 211:33-45. | Article | PubMed

58. Schafer EC and Thibodeau LM. Speech recognition abilities of adults using cochlear implants with FM systems. J Am Acad Audiol. 2004; 15:678-91. | Article | PubMed

59. Fu QJ, Shannon RV and Wang X. Effects of noise and spectral resolution on vowel and consonant recognition: acoustic and electric hearing. J Acoust Soc Am. 1998; 104:3586-96. | Pdf | PubMed

60. Fu QJ and Nogaki G. Noise susceptibility of cochlear implant users: the role of spectral resolution and smearing. J Assoc Res Otolaryngol. 2005; 6:19-27. | Article | PubMed Abstract | PubMed Full Text

61. Qazi OU, van Dijk B, Moonen M and Wouters J. Understanding the effect of noise on electrical stimulation sequences in cochlear implants and its impact on speech intelligibility. Hear Res. 2013; 299:79-87. | Article | PubMed

62. Loizou PC, Lobo A and Hu Y. Subspace algorithms for noise reduction in cochlear implants. J Acoust Soc Am. 2005; 118:2791-3. | Article | PubMed Abstract | PubMed Full Text

63. Li X, Nie K, Imennov NS, Won JH, Drennan WR, Rubinstein JT and Atlas LE. Improved perception of speech in noise and Mandarin tones with acoustic simulations of harmonic coding for cochlear implants. J Acoust Soc Am. 2012; 132:3387-98. | Article | PubMed

64. Gifford RH, Olund AP and Dejong M. Improving speech perception in noise for children with cochlear implants. J Am Acad Audiol. 2011; 22:623-32. | Article | PubMed

65. Garadat SN, Zwolan TA and Pfingst BE. Using temporal modulation sensitivity to select stimulation sites for processor MAPs in cochlear implant listeners. Audiol Neurootol. 2013; 18:247-60. | Article | PubMed

66. Srinivasan AG, Padilla M, Shannon RV and Landsberger DM. Improving speech perception in noise with current focusing in cochlear implant users. Hear Res. 2013; 299:29-36. | Article | PubMed

67. Bierer JA, Bierer SM and Middlebrooks JC. Partial tripolar cochlear implant stimulation: Spread of excitation and forward masking in the inferior colliculus. Hear Res. 2010; 270:134-42. | Article | PubMed Abstract | PubMed Full Text

68. Kahneman D. Attention and effort. 1973. | Book

69. Kahneman D. Thinking, Fast and Slow. Macmillan. 2011. | Book

70. Hughes KC and Galvin KL. Measuring listening effort expended by adolescents and young adults with unilateral or bilateral cochlear implants or normal hearing. Cochlear Implants Int. 2013. | Article | PubMed

71. Dunn CC, Noble W, Tyler RS, Kordus M, Gantz BJ and Ji H. Bilateral and unilateral cochlear implant users compared on speech perception in noise. Ear Hear. 2010; 31:296-8. | Article | PubMed Abstract | PubMed Full Text

72. Pals $C$, Sarampalis A and Baskent D. Listening effort with cochlear implant simulations. J Speech Lang Hear Res. 2013; 56:1075-84. Article | PubMed

73. Hornsby BW. The effects of hearing aid use on listening effort and mental fatigue associated with sustained speech processing demands. Ear Hear. 2013; 34:523-34. | Article | PubMed

74. Baer T, Moore BC and Gatehouse S. Spectral contrast enhancement of speech in noise for listeners with sensorineural hearing impairment: effects on intelligibility, quality, and response times. J Rehabil Res Dev. 1993; 30:49-72. I PubMed

75. Gatehouse $\mathrm{S}$ and Gordon J. Response times to speech stimuli as measures of benefit from amplification. Br J Audiol. 1990; 24:63-8. | Article | PubMed

76. Zekveld AA, Kramer SE and Festen JM. Pupil response as an indication of effortful listening: the influence of sentence intelligibility. Ear Hear. 2010; 31:480-90. | Article | PubMed

77. Gosselin PA and Gagné JP. Use of a Dual-Task Paradigm to Measure Listening Effort. Canadian J Spch Lang Path \& Audiol. 2010; 34:43. | Article

78. Doherty KA and Desjardins JL. The Practical Hearing Aids Skills TestRevised. Am J Audiol. 2012; 21:100-5. | Article | PubMed

79. Gosselin PA and Gagne JP. Older adults expend more listening effort than young adults recognizing audiovisual speech in noise. Int $J$ Audiol. 2011; 50:786-92. | Article | PubMed

80. Wright $\mathrm{R}$ and Uchanski RM. Music perception and appraisal: cochlear implant users and simulated cochlear implant listening. J Am Acad Audiol. 2012; 23:350-65; quiz 379. | Article | PubMed

81. Gfeller K, Christ A, Knutson JF, Witt S, Murray KT and Tyler RS. Musical backgrounds, listening habits, and aesthetic enjoyment of adult cochlear implant recipients. J Am Acad Audiol. 2000; 11:390-406. | PubMed

82. Gfeller K, Oleson J, Knutson JF, Breheny P, Driscoll V and Olszewski C Multivariate predictors of music perception and appraisal by adult cochlear implant users. J Am Acad Audiol. 2008; 19:120-34. | Article | PubMed Abstract | PubMed Full Text

83. Drennan WR and Rubinstein JT. Music perception in cochlear implant users and its relationship with psychophysical capabilities. J Rehabil Res Dev. 2008; 45:779-89. | Article | PubMed Abstract | PubMed Full $\underline{\text { Text }}$

84. Limb CJ and Roy AT. Technological, biological, and acoustical constraints to music perception in cochlear implant users. Hear Res. 


\section{3, "In Press". | Article | PubMed}

85. Shannon RV, Zeng FG, Kamath V, Wygonski J and Ekelid M. Speech recognition with primarily temporal cues. Science. 1995; 270:303-4. I Article I PubMed

86. Friesen $L M$, Shannon RV, Baskent $D$ and Wang $X$. Speech recognition in noise as a function of the number of spectral channels: comparison of acoustic hearing and cochlear implants. J Acoust Soc Am. 2001; 110:1150-63. | Article | PubMed

87. Smith ZM, Delgutte $B$ and Oxenham AJ. Chimaeric sounds reveal dichotomies in auditory perception. Nature. 2002; 416:87-90. | Article | PubMed Abstract | PubMed Full Text

88. Li X, Nie K, Imennov NS, Rubinstein JT and Atlas LE. Improved perception of music with a harmonic based algorithm for cochlear implants. IEEE Trans Neural Syst Rehabil Eng. 2013; 21:684-94. | Article I PubMed

89. Galvin JJ, 3rd, Fu QJ and Nogaki G. Melodic contour identification by cochlear implant listeners. Ear Hear. 2007; 28:302-19. | Article | PubMed Abstract | PubMed Full Text

90. Galvin JJ, 3rd, Fu QJ and Shannon RV. Melodic contour identification and music perception by cochlear implant users. Ann N Y Acad Sci. 2009; 1169:518-33. | Article | PubMed Abstract | PubMed Full Text

91. Gfeller K, Witt S, Adamek M, Mehr M, Rogers J, Stordahl J and Ringgenberg $\mathrm{S}$. Effects of training on timbre recognition and appraisal by postlingually deafened cochlear implant recipients. J Am Acad Audiol. 2002; 13:132-45. | PubMed

92. Hsiao F and Gfeller K. Music Perception of Cochlear Implant Recipients with Implications for Music Instruction: A Review of Literature. Update Univ S C Dep Music. 2012; 30:5-10. | Article | PubMed Abstract I PubMed Full Text

93. Driscoll VD. The Effects of Training on Recognition of Musical Instruments by Adults with Cochlear Implants. Semin Hear. 2012; 33:410-418. | Article | PubMed Abstract | PubMed Full Text

94. Nimmons GL, Kang RS, Drennan WR, Longnion J, Ruffin C, Worman T, Yueh B and Rubenstien JT. Clinical assessment of music perception in cochlear implant listeners. Otol Neurotol. 2008; 29:149-55. | Article | PubMed Abstract | PubMed Full Text

95. Kang R, Nimmons GL, Drennan W, Longnion J, Ruffin C, Nie K, Won JH, Worman T, Yueh B and Rubinstein J. Development and validation of the University of Washington Clinical Assessment of Music Perception test. Ear Hear. 2009; 30:411-8. | Article | PubMed Abstract | PubMed Full Text

96. Ponton CW and Eggermont JJ. Of kittens and kids: altered cortical maturation following profound deafness and cochlear implant use. Audiol Neurootol. 2001; 6:363-80. | Article | PubMed

97. Dorman MF, Sharma A, Gilley P, Martin K and Roland P. Central auditory development: evidence from CAEP measurements in children fit with cochlear implants. J Commun Disord. 2007; 40:28494. | Article | PubMed Abstract | PubMed Full Text

98. Ponton CW, Don M, Eggermont JJ, Waring MD and Masuda A. Maturation of human cortical auditory function: differences between normal-hearing children and children with cochlear implants. Ear Hear. 1996; 17:430-7. | Article | PubMed

99. Nosofsky RM. Attention and learning processes in the identification and categorization of integral stimuli. J Exp Psychol Learn Mem Cogn. 1987; 13:87-108. | Article | PubMed

100. Goldstone R. Influences of categorization on perceptual discrimination. J Exp Psychol Gen. 1994; 123:178-200. | Article | PubMed

101. Goldstone RL. Perceptual learning. Annu Rev Psychol. 1998; 49:585612. | Article | PubMed

102. Fu QJ and Galvin JJ, 3rd. Perceptual learning and auditory training in cochlear implant recipients. Trends Amplif. 2007; 11:193-205. | Article | PubMed Abstract | PubMed Full Text

103. Stacey PC, Raine CH, O'Donoghue GM, Tapper L, Twomey T and Summerfield AQ. Effectiveness of computer-based auditory training for adult users of cochlear implants. Int J Audiol. 2010; 49:347-56. | Article | PubMed

104. Boothroyd A. Adapting to changed hearing: the potential role of formal training. J Am Acad Audiol. 2010; 21:601-11. | Article | PubMed

105. Litovsky RY, Goupell MJ, Godar S, Grieco-Calub T, Jones GL, Garadat SN, Agrawal S, Kan A, Todd A, Hess C and Misurelli S. Studies on bilateral cochlear implants at the University of Wisconsin's Binaural Hearing and Speech Laboratory. J Am Acad Audiol. 2012; 23:476-94. | Article | PubMed Abstract | PubMed Full Text

106. Aronoff JM, Yoon YS, Freed DJ, Vermiglio AJ, Pal I and Soli SD. The use of interaural time and level difference cues by bilateral cochlear implant users. J Acoust Soc Am. 2010; 127:EL87-92. | Article | PubMed Abstract | PubMed Full Text

107. Chan JC, Freed DJ, Vermiglio AJ and Soli SD. Evaluation of binaural functions in bilateral cochlear implant users. Int J Audiol. 2008; 47:296-310. | Article | PubMed

108. Litovsky RY, Parkinson A and Arcaroli J. Spatial hearing and speech intelligibility in bilateral cochlear implant users. Ear Hear. 2009; 30:419-31. | Article | PubMed Abstract | PubMed Full Text

109. Dunn CC, Perreau A, Gantz B and Tyler RS. Benefits of localization and speech perception with multiple noise sources in listeners with a short-electrode cochlear implant. J Am Acad Audiol. 2010; 21:44-51. | Article | PubMed Abstract | PubMed Full Text

110. Goupell MJ, Stoelb C, Kan A and Litovsky RY. Effect of mismatched place-of-stimulation on the salience of binaural cues in conditions that simulate bilateral cochlear-implant listening. J Acoust Soc Am. 2013; 133:2272-87. | Article | PubMed

111. Gordon KA, Chaikof MH, Salloum C, Goulding G and Papsin B. Toward a method for programming balanced bilateral cochlear implant stimulation levels in children. Cochlear Implants Int. 2012; 13:220-7. Article | PubMed

112. Smith ZM and Delgutte B. Sensitivity of inferior colliculus neurons to interaural time differences in the envelope versus the fine structure with bilateral cochlear implants. J Neurophysiol. 2008; 99:2390-407. | Article | PubMed Abstract | PubMed Full Text

113. Peters BR, Wyss $J$ and Manrique $M$. Worldwide trends in bilateral cochlear implantation. Laryngoscope. 2010; 120 Suppl 2:S17-44. | Article | PubMed

114. Ramsden JD, Papsin BC, Leung R, James A and Gordon KA. Bilateral simultaneous cochlear implantation in children: our first 50 cases. Laryngoscope. 2009; 119:2444-8. | Article | PubMed

115. Hancock KE, Noel V, Ryugo DK and Delgutte B. Neural coding of interaural time differences with bilateral cochlear implants: effects of congenital deafness. J Neurosci. 2010; 30:14068-79. | Article | PubMed Abstract | PubMed Full Text

116. Hancock KE, Chung $Y$ and Delgutte $B$. Congenital and prolonged adultonset deafness cause distinct degradations in neural ITD coding with bilateral cochlear implants. J Assoc Res Otolaryngol. 2013; 14:393-411. | Article | PubMed

117. Papsin BC and Gordon KA. Bilateral cochlear implants should be the standard for children with bilateral sensorineural deafness. Curr Opin Otolaryngol Head Neck Surg. 2008; 16:69-74. | Article | PubMed

118. Gordon KA, Jiwani S and Papsin BC. What is the optimal timing for bilateral cochlear implantation in children? Cochlear Implants Int. 2011; 12 Suppl 2:S8-14. | Article | PubMed

119. Chadha NK, Papsin BC, Jiwani S and Gordon KA. Speech detection in noise and spatial unmasking in children with simultaneous versus 
sequential bilateral cochlear implants. Otol Neurotol. 2011; 32:1057-64. | Article | PubMed

120. Gordon KA and Papsin BC. Benefits of short interimplant delays in children receiving bilateral cochlear implants. Otol Neurotol. 2009; 30:319-31. | Article | PubMed

121. Gordon KA, Wong DD and Papsin BC. Bilateral input protects the cortex from unilaterally-driven reorganization in children who are deaf. Brain. 2013; 136:1609-25. | Article | PubMed

122. Brainard MS and Knudsen El. Brain development, V: Experience affects brain development. Brain development, V: Experience affects brain development. Am J Psychiatry. 1998; 155:1000. I Article

123. Siveke I, Leibold C, Schiller E and Grothe B. Adaptation of binaural processing in the adult brainstem induced by ambient noise. $J$ Neurosci. 2012; 32:462-73. I Article I PubMed

124. Dahmen JC and King AJ. Learning to hear: plasticity of auditory cortical processing. Curr Opin Neurobiol. 2007; 17:456-64. | $\underline{\text { Article I PubMed }}$

125. Potts LG and Litovsky RY. Transitioning from Bimodal to Bilateral Cochlear Implant Listening: Speech Recognition and Localization in Four Individuals. Am J Audiol. 2013. | Article | PubMed

126. Litovsky RY. Review of recent work on spatial hearing skills in children with bilateral cochlear implants. Cochlear Implants Int. 2011; 12 Suppl 1:S30-4. | Article | PubMed Abstract | PubMed Full Text

127. Rubinstein JT. Cochlear implants: the hazards of unexpected success. CMAJ. 2012; 184:1343-4. | Article | PubMed Abstract | PubMed Full Text

128. Nauta WJH. Discussion of "Retardation and facilitation in learning by stimulation of frontal cortex in monkeys." In: M WJ, K A, eds. The Frontal Granular Cortex and Behavior. New York: McGraw-Hill International; 1964:125. | Book

129. Arlinger S, Lunner T, Lyxell B and Pichora-Fuller MK. The emergence of cognitive hearing science. Scand J Psychol. 2009; 50:371-84. | Article | PubMed

\section{Citation:}

Faulkner KF and Pisoni DB. Some observations about cochlear implants: challenges and future directions. Neurosci Discov. 2013; 1:9.

http://dx.doi.org/10.7243/2052-6946-1-9 